\title{
PRIMO LEVI AND HUNGER
}

\section{DANiELA BisEllo ANTONUCCI}

Summary: When Primo Levi was deported to Auschwitz in 1944, he suffered from physical hunger. But the association of this real hunger-the lack of food-with his other desperate hunger-his desire to tell his story-created the energy to make a connection with the world after the Lager experience. This study shows how Levi's eagerness to write about his other hunger animated and supported his appetite for life. By doing so, Levi obtained the knowledge he needed to understand it, and be able to live after the Lager.

Il male che affligge il mondo non è soltanto rappresentato dalla fame del "pane quotidiano" ma altresi di sapere, di conoscere, di evoluzione. (The illness that plagues the world is not just the hunger for "daily bread" but also for knowledge, understanding, to achieve progress.)1

For Primo Levi, the renowned writer from Turin and recipient of the distinguished literary Strega, Campiello and Viareggio awards, "knowledge and understanding" became his means of survival after his return from Auschwitz. Born in Turin in 1919, Levi spent most of his life there until his death in 1987.

His Jewish identity was not felt as a sign of 'difference' until July 1938, when the Fascist government introduced the racial laws in Italy, which prevented Jews from attending public schools, working in public institutions or owning property.

From that moment on, life for Levi and many Jews in Italy became uncertain and precarious and, as a result, in 1944 after joining the partisan movement, he was arrested by the Fascist Militia and sent to an internment camp for Jews in Fossoli. Shortly thereafter on February 11, 1944 he was transferred to Auschwitz, where he spent eleven strenuous and unforgettable months. Even after the liberation of the camp by the Russian troops, Levi was not able to return home for another nine months; both his experience in the camp and his journey home had a fundamental impact on his life and significant moments of those experiences are narrated in his books.

In the introduction to Understanding Primo Levi, Nicholas Patruno describes Primo Levi as "one of the most incisive and candid intellects

1 Arata, Guerra e Fame, 36. Unless otherwise noted all translations from Italian are mine. 
among those writers who experienced the Holocaust and survived to tell us about it."2 Levi showed interest and passion for the "Holocaust" specifically in the Sixties when this term was introduced to define not only a way to spread information about the Shoah, but also as a means to convey testimony of it to them.

Levi "eventually embraced the role of Holocaust educator," 3 joining many concentration camp survivors whose compelling desire was to provide evidence of the atrocity they all experienced and, at the same time, to confront it. As a result of his being affected by his stay in Auschwitz, he devoted most of the rest of his life to informing people about the inhuman conditions of the concentration camps and the profound impact that the ordeal had on him and his camp mates.

This was not an easy undertaking because, according to Domenico Scarpa, Levi's attempt to try "not to forget" was "a battle against oblivion": "Se parleremo non ci ascolteranno, e se ci ascoltassero non ci crederebbero" (If we speak they will not listen to us, and if they listened they would not believe us). 4

In Auschwitz he was forced to face two enemies: the persecutor and the persecutor's determination to erase all the possible traces of the victims' conditions there. 5

While reading Levi's works, in particular If This Is a Man, The Periodic Table and some of his short stories, it is impossible not to be impressed by the numerous times the word hunger is mentioned:

Ho fame, e domani quando distribuiranno la zuppa come farò a mangiarla senza cucchiaio? (I am hungry and when they give out the soup tomorrow how will I be able to eat it without a spoon?) (Levi, Se questo è un uomo, 33).

Nonostante la fame, non passano dieci minuti che sono addormentato. (Notwithstanding the hunger, I fall asleep in ten minutes) (Levi, Se questo è un uomo, 44)

Potremo forse sopravvivere alle malattie e sfuggire alle scelte, forse anche resistere al lavoro e alla fame che ci consumano, e dopo? (We might perhaps be able to survive diseases and avoid being chosen, perhaps even survive the fatigue and the hunger that consume us, but what will happen later?) (Levi, Se questo è un uomo, 49)

2 Patruno, Understanding Primo Levi, 1995, 1.

3 Harrowitz, "Primo Levi Jewish Writer," 20.

4 Levi, Se questo è un uomo, 23.

$5 \mathrm{Al}$ di quà del bene e del male, 48 . 
Ogni due o tre ore ci dobbiamo alzare, per smaltire la grossa dose di acqua che siamo costretti ad assorbire sotto forma di zuppa, per soddisfare la fame. (Every two or three hours we must get up to eliminate the huge amount of water which we are made to absorb in the form of soup, to satisfy hunger.) (Levi, Se questo è un uomo, 54)

Finché la fame, o il freddo, o la pienezza della vescica non convogliano i sogni entro gli schemi consueti. (Till hunger, or cold, or bladder fullness channel our dreams into their usual pattern.) (Levi, Se questo è un uomo, 56)

This frequent occurrence would suggest that the word 'hunger/fame' stands for more than just physical deprivation; Levi's hunger was also psychological, emotional, and intellectual. During his countless interviews in the years after Auschwitz, Levi repeatedly mentioned his obsession about not being able to recount or remember completely all the events he witnessed in the Lager. The association of his real hunger resulting from lack of food, with his other impelling hunger, his unquestionable desire to tell his story, produced the 'energy' needed to connect with the world after Auschwitz.

As a result, he vigorously questioned himself and the rest of the world about the existence of human brutality and the true meaning of the word 'human.' This is better conveyed by the title Se questo è un uomo (If This Is a Man $)^{6}$ rather than by the widely used title of the American translation of Levi's book, Survival in Auschwitz. The title If This Is a Man better depicts his emotional condition and communicates a deeper significance to the reader as it invites consideration of the (in)human conditions of life in the concentration camp, rather than the more stagnant portrayal of life in the Lager as the title Survival in Auschwitz evokes.

Un testimone anche se è una vittima, deve parlare pacatamente e sobriamente, non con la lingua del vendicatore. Un testimone offre al giudice il modo di giudicare. Io sono il testimone, il giudice siete voi.(A witness even though he is a victim, must speak soberly and placidly, not using the avenger's language. A witness offers the judge the way to judge. I am the witness, you are the judge. $)^{7}$

As Gabriella Poli stated in her study about Levi's role as a witness, we, the readers of his books, have the responsibility to accept or reject, approve or disapprove his testimony. In order to be fair judges, we must consider

6 Translation by Stuart Wolf, London: Orion Press, 1959.

7 Poli, "La memoria come impegno e come lotta," 29. 
the implications involved in the testimony and, consequently, recognize the hardship he was forced to endure and better comprehend his transformation as a human being because "noi non eravamo normali perché avevamo fame" (we were not normal because we were hungry). ${ }^{8}$ This hunger, that was the torment of the prisoners' daily life, that was felt in every cell in their body, profoundly affected their behavior. Eating and acquiring food was the most significant purpose of each day in Auschwitz, and interwoven within the memory of that goal, in the years after his return home, was also his recurrent need to recount his experience, to make sure that people knew everything before he could forget. His compelling need to tell and tell again about his lager days could be easily associated with the compelling need he experienced there to search for food because it was

un istinto abbastanza giustificato: volevo cioè liberarmene (a rather justified instinct: I wanted in fact to set myself free of it.) $)^{9}$

Telling and later writing about his experience in the camp was a way to exorcize the memory of a horrendous period of his life which in the end not only strengthened him but it became 'his university.' He eventually realized that he had begun writing If This Is a Man in that German lab pervaded by the freezing cold, the presence of war and intrusive looks without even knowing it. ${ }^{10}$ The reference to Coleridge's Ancient Mariner is unmistakable: it is apparent in the incessant recounting, in the feeling that the recounting is a form of penance and therefore the obligation to tell his story any time the agony returns. In a way similar to the Ancient Mariner, Levi is compelled to tell his story of hunger to describe what is often indescribable and to assure, even himself, that such an atrocity really happened to the point of feeling satiated by his own tales.

E in treno mi ricordo di aver raccontato le mie cose ai primi che capitavano. Ho citato a questo proposito il vecchio marinaio di Coleridge, che racconta la sua storia a gente che va a nozze e se ne infischia di lui.(And I remember that on the train I told my story to anybody who was there and to this regard I cited Coleridge's ancient mariner who, at a wedding, tells his story to people who do not care about it. ${ }^{11}$

8 Levi, Il sistema periodico, 143.

9 Conversazioni e interviste, 178.

10 Conversazioni e interviste, 129.

11 Conversazioni e interviste, 129. 
This irresistible impulse to write for many of those who survived the camp was the equivalent of therapy but for Levi the therapeutic effect was checked by the lack of proper lexicon to describe those events.

Allora per la prima volta ci siamo resi conto che la nostra lingua manca di parole per esprimere questa offesa, la demolizione di un uomo (Then for the first time we realized that our language lacks words to express this offense, the demolition of a man.) ${ }^{12}$

Levi's writing, although essential and concise, is capable of giving a detailed account of what Patruno defined as 'irrational.' But when Levi wrote his books he was rational and completely conscious of his physical and emotional condition. He was concerned about his inability to report and to depict meticulously, among other conditions, the notion of not knowing what it meant for him and his camp mates not to feel hunger.

Ma come si potrebbe pensare di non avere fame? Il Lager è la fame: noi stessi siamo la fame, fame vivente. (But how could it be possible to think of not being hungry? The lager is hunger: we are hunger, living hunger.) (Levi, Se questo è un uomo, 66)

The account of his and his camp mates' hunger is clearly and unquestionably narrated in many pages of If This Is a Man. Usually these accounts follow the experience of their physical and emotional distress in their attempt to leave proof of that 'historical truth' which, at that time, the Nazis strove to control. "The drowned" would probably be the best voices to listen to because they were the ones who suffered the most, "the saved," like Levi, must convey their own suffering and interpret what others suffered.

In the first chapter of If This Is a Man, in the section called "Il viaggio" (The Journey), the reference to food is related to mothers and children:

Se dovessero uccidervi domani col vostro bambino voi non gli dareste oggi da mangiare? (If they were to kill you and your child tomorrow, wouldn't you give him something to eat today?) (Levi, Se questo è un uomo, 13)

For those mothers the concept of 'feeding' their children seemed to be very natural, but what does not seem natural is the connection with death. This is probably related to what Patruno describes as 'irrational:' how 
could you possibly think of feeding your child when you were sentenced to death? But Levi knew what those mothers did not know. They were only concerned about their children and their only worry, prompted by their maternal instincts, was to make sure that their children were fed; they were not aware of the imminent death.

But hunger in the lager had a very peculiar significance and Levi's desire was to adequately evidence that condition. In almost every page of If This Is a Man there is mention or reference to that word-hunger- because Levi thinks that that "la fame cronica è sconosciuta agli uomini liberi" (chronic hunger is unknown to free men) (Levi, Se questo è un uomo, 31).

Levi's description of hunger varies from a detailed account of the calories they were consuming to the value of certain items that could be used in exchange for bread (one could exchange a spoon for three rations of bread) or any other available form of nourishment. In Auschwitz bread was an expensive item to trade. At times prisoners would take a bowl of soup left behind by someone who had died, risking death from contamination. In fact:

Chi poteva aver avanzato mezza scodella di zuppa in quel regno della fame?...Ma ad Auschwitz cautele di questo tipo non avevano corso, prima veniva la fame e poi tutto il resto. (Who could have left behind half a bowl of soup in that kingdom of hunger?...But there were not such precautions in Auschwitz, hunger came first and then everything else.) (Levi, Lultimo Natale di Guerra, 58)

As hunger remains a constant presence in the recollection of those horrendous days, it eventually becomes the true protagonist of the Lager tales. Levi speaks about it incessantly in an effort to express the indescribable and he does so with the same perseverance that he demonstrates when offering his testimony of it.

Food and the lack of it was the topic of daily conversations with his camp mates and it was the inseparable companion of their nights. There was not a moment in which Levi or the other prisoners were not in close contact with the notion of hunger. The only tangible sensations he was never free from were hunger, cold and fatigue. He could not envision his days without them and, consequently, even his dreams were influenced by his food deprivation. He dreamt about himself at home, sitting with his legs under the table (a direct contrast with eating standing up in the lager), and with plenty of food on it.

Closely connected with hunger Levi experienced the most tragic condition, what Lidia Beccaria Rolfi (a deportee herself) defined as the "trans- 
formation into a subhuman.”

Far capire come l'uomo fosse stato offeso: l'uomo privato del suo nome, tatuato come un animale, obbligato a leccare la zuppa come i cani, disumanizzato, trasformato in un subuomo. (To make people understand how man had been offended, deprived of his own name, tattooed like an animal, forced to lick his soup like a dog, dehumanized, turned into a subhuman.) (Beccaria Rolfi, "La memoria dopo il ritorno", 56)

Along with that compelling physical condition and his dehumanized state there was another type of hunger:

la pena del ricordarsi, il vecchio feroce struggimento di sentirsi uomo, che mi assale come un cane all'istante e...allora prendo la matita e il quaderno e scrivo quello che non saprei dire a nessuno. (The pain of remembering, the old ferocious pain of feeling like a man, which instantly assails me like a dog and...then I take the pencil and the notebook and I write what I could not tell anybody). (Levi, Se questo è un uomo, 126)

'Those notes' were the immediate testimony of what Levi later recorded in books and reported in conversations during public appearances. The original pain of remembering found in his soul a profound desire to share his experience along with a determination to give evidence of that 'historical truth' that the Nazis tried to erase, manipulating the prisoners and imposing severe punishment if they were found with anything that could identify what happened in the camps.

The close relationship between hunger and food not only widens the notion of the theme of food, but for a hungry person, the instinct for energy conservation overrides every other impulse apart from chasing after the slightest scrap of food. ${ }^{13}$ Consequently, the starving person is driven by this instinct to look for 'something' that could satisfy his/her need for 'energy'. In the case of Levi, writing about his own hunger provided this necessary energy. His hunger was transformed into a need which was his appetite for life. Raymond Tallis discusses, in his book Hunger, the significance of desire as "an appetite that has a story" and explains that it is "a hunger that narrates itself and tries to make sense of itself. Through the sense we make of our desires we make sense of ourselves and we tell ourselves and others stories about what we have been and what we are going to be. The importance of these stories is that they mark the point at which appetites become

13 Tallis, Hunger 25. 
desires." 14 As long as Levi could write about his own memories he could 'taste' very important fragments of his own past life and find the essential force to live. In an easy marriage of contrasts, to be sated is to be not-hungry; Levi felt satiated by revisiting and contemplating his own past and, as a result, his other hunger was satisfied. The profound need for acknowledgment by others was inevitable for Levi and he spent his entire life 'feeding' his own hunger. When this force faded away, his depression prevailed and his appetite for life departed, causing his death.

Many critics have explored the importance of Levi's testimony about his Lager experience. Ian Thompson, one of Levi's biographers, noticed that after the intense nightmare of Auschwitz, everything seemed colorless, futile and false to Levi. ${ }^{15}$ On the first night of his homecoming, Levi slept with a piece of bread hidden under his pillow, and although his homecoming helped him to live again, he found the strength in those notes that he had very carefully preserved. In those notes there was the truth of what history labeled "the Holocaust". Writing provided Levi with a reason to live and the pain of remembering was replaced by his desire/hunger to tell and tell again what he witnessed. At the time of his captivity he and his mates deliberately decided not to understand because

la nostra saggezza era il non cercar di capire, non rappresentarsi il futuro, non porre e non farsi domande. (Our wisdom was not trying to understand, not to imagine the future, not to ask anybody or ourselves questions.) (Levi, Se questo è un uomo,104)

The only tangible reality Levi had was his hunger and his desolation, the rest did not exist as "history had stopped" in the Lager.

The reasoning about his experience in Auschwitz came later when a new chapter of his life was started: his becoming a writer. Without the Auschwitz experience he probably would not have considered the opportunity to become a writer. Writing and intellectualizing about the Lager experience gave him the strength to overcome the fear of understanding it. His works reflect, as Marina Beer acknowledged, all the possible 'questions' that the literature of testimony could cover: narrator and protagonist, the time frame of narrating and the one of memory, and the relationship between living and written memory.16 Even though Levi did not leave his

14 Tallis, Hunger, 81.

15 Thomson, "The Genesis of If This is a Man," 42.

16 Beer, "Memoria cronaca e storia," 610. 
job as a chemist at SIVA, till his retirement, he ultimately became a writer. He narrated with a positive inclination and he attempted to provide a coherent and objective commentary. His well-structured and logical style of writing allowed him to communicate the moments of his Lager life and to create, at the same time, a literary language characterized by a sad but non-pessimistic tone. His scientific disposition is evident in the clear and efficient way he describes events. That essential language, the interchangeable use of the first person singular and plural, and his intended emotional distance allowed him to narrate without being influenced by personal feelings of hate or rancor. He wrote sincerely with little emotional involvement; his detached attitude allowed him to report facts in a way that inspired great interest and attraction for his books. Critics have tried to see all sorts of correlations with literary genres in his works and have debated his role as a 'Jewish' writer. What Mario Belpoliti said about his works helps describe and define him succinctly:

Levi fornisce al lettore un distillato di pensieri e riflessioni, non di sentimenti. È insomma uno scrittore che punta sull'intelligenza del lettore. (Levi gives the reader a selection of thoughts and observations, not emotions. His goal as a writer is to reach the reader's intelligence. $)^{17}$

During the years after the rather subdued publication of If This Is a Man (1947), Levi had an opportunity to revisit his days in the Lager, allowing himself to take a closer look at his imprisonment and his life before and after his deportation to Auschwitz.

He was then invited to participate in many television programs, as people wanted to hear from him the 'true' tale of the concentration camps. His book, If This Is a Man, became a play and it was broadcast by RAI in 1964 and then adapted for the stage at the Teatro Stabile di Torino in 1966. His testimony had become a strong voice and it also represented his hunger for recognition and acknowledgement. What happened in Levi's past and why — the meaning of those events being inseparable — created a motivation for him to continue his public appearances. As Marcel Proust suggested - remembering is not simply searching but it is also creating 18 - Levi not only retrieved the 'pre-made' pieces of his past, but he recreated them through his hunger/desire to recount them over and over. And as a result, his need to write about it was his 'fuel' for living, his own nourishment.

17 Belpoliti, "Animali e fantasmi," 133.

18 Proust, À la recherche du temps perdu, 1913-1927. 
In 1975, Levi published The Periodic Table which has been defined as a double autobiography - "autobiografia del chimico in quanto testimone e autobiografia del testimone in quanto chimico" (the chemist's autobiography because he was a witness and the witness's autobiography because he was a chemist). ${ }^{19}$ The book is divided into 21 chapters, each titled after an element of Mendeleev's periodic table. Each chapter reveals moments of Levi's life with the exception of two, which are entirely invented. In the chapter entitled "Cerio" (Cerium), Levi opens the narration by saying:

A distanza di trent'anni, mi riesce difficile ricostruire quale sorta di esemplare umano corrispondesse, nel novembre 1944, al mio nome, o meglio al mio numero 174517 . (Thirty years later, it is difficult for me to retrace the kind of human specimen that corresponded to my name, or better to my number 174517.) (Levi, Il sistema periodico, 142)

Revisiting the Auschwitz days thirty years later confirmed Levi's desire to 'tell and tell again', but also his compelling need to better comprehend how he lived in an environment "infettato dalla presenza quotidiana della morte" (infected by the daily presence of death) (Levi, Il Sistema Periodico, 141). Once again, the daily presence of death was conveyed by the entrenched notion of hunger that Levi defined as something completely different from the common awareness of 'feeling' hungry after skipping a meal.

The constant recurrence of the notion of hunger, still very vivid in his memory thirty years later, joins his longing for understanding the irrational' experienced in Auschwitz. He then admits that "rubavo per mangiare" (I stole in order to eat). He stole everything he could use to barter for food but he never stole bread from his camp mates. When he stole the cerium from the chemist lab he realized that he could not trade it because it would be of no use except to ignite a fire and he was sad and disappointed at the same time. His friend Alberto reproached him saying that

Non bisogna scoraggiarsi mai, perché è dannoso, e quindi immorale, quasi indecente. (You must never lose heart, because it is dangerous and therefore immoral, almost indecent.) (Levi, Il Sistema Periodico, 147)

There was in fact an illegal market of cigarette lighters in the camp and the cerium could be used for that and be exchanged for bread. He and Alberto worked for three nights to prepare the cerium and by doing that, they assured two months' supply of food and, as Levi described, "they acquired

19 Beer, "Memoria cronaca e storia," 609. 
the bread that kept them alive till the arrival of the Russians." That dangerous action was legitimized by the strong will to survive and writing these stories for him was the 'therapy' needed to explain the immorality of his action in order to understand it.

Scrivevo disordinatamente pagine su pagine di ricordi che mi avvelenavano, ed i colleghi mi guardavano di sottecchi come uno squilibrato innocuo. (I used to write disorderly pages and pages of memories which were poisoning me, while my colleagues used to look at me as a harmless crazy man.) (Levi, Il Sistema Periodico, 156)

The writing therapy started to work and the burden of horrendous memories became Levi's salvation.

Non piú l'itinerario doloroso di un convalescente, non piú un mendicare compassione e visi amici, ma un costruire lucido, ormai non piú solitario.(No longer the painful itinerary of a convalescent, no longer begging for sympathy and friendly faces, but clear creation, not lonely any longer.) (Levi, Il Sistema Periodico, 157)

His compelling desire to tell and retell at the time of The Periodic Table had established in him a form of conviction that he did not have before, as he could finally face the ghosts of his memories. This decisive turning point in his attitude as a veteran of the lager experience is traceable in the chapter entitled "Vanadio" (Vanadium) when the narrator finds himself "da uomo a uomo a fare i conti con uno degli altri" (in a man to man confrontation with one from the other side) (219). Levi had been waiting for that confrontation since his return from Auschwitz and he had often dreamt about it in German, but he also admitted he was afraid of facing it. The narration of the accidental meeting with Dr. Müller, the German lab supervisor during his imprisonment in Auschwitz, is characterized by a very detached tone which allows him to reason about the event. The shipment of defective resin gave Levi the opportunity to reexamine the emotions associated with the painful stay in the lager. The writing therapy (the contact with Dr. Muller was by letter) helped him see in his enemy a human being seeking absolution. Dr. Müller asked for a meeting and Levi, who was not ready for the confrontation, emphasized that

Non mi sentivo di rappresentare i morti di Auschwitz e neppure mi pareva sensato ravvisare in Müller il rappresentate dei carnefici (I did not feel entitled to play the role of the Auschwitz's dead nor did I consider it sensible to recognize in Müller the embodiment of the executioners.) (Levi, Il Sistema Periodico, 225) 
Understanding that forgiveness was more important for the enemy than for the victim; it gave Levi the strength that satisfied his hunger.

Between 1977 and 1987, Levi wrote several short stories which were published posthumously for the first time in 2000. The collection entitled Racconti Dispersi (Scattered Stories), assembles different genres, from the autobiographical to the fantastic. In the story "Auschwitz cittá tranquilla" (Auschwitz, quiet town) written in 1984, Levi returns to his camp days:

Eppure eravamo oltre che spaventati, umiliati e disperati, anche curiosi: affamati di pane ma anche di capire (and yet besides being scared, humiliated and desperate, we were also curious: hungry for bread but also for understanding.) (Levi, L’ultimo Natale di Guerra, 31)

This assertion not only confirms the recurrent presence of his hunger but also associates it with its evolution into a desire/need for comprehension. The physical hunger of the Lager is now replaced by the intellectual/spiritual hunger. It is interesting to note that the author chooses Mertens, a young German Catholic, as a vehicle of this transition; he is a chemist like Levi whom he met by "strange, even provocative fate." Differently from Dr. Müller, Mertens avoided discussing Auschwitz. His excessive drinking allowed him to anaesthetize his emotions and avoid the confrontation of a topic that would put him in a very difficult position. Mertens does not possess Levi's strength; he is, on the contrary, weak and unable to challenge himself. He chooses to hide his feelings of guilt and responsibility. When forced to answer questions, Mertens admitted his 'obedience' to Hitler and explained that he did not know about the gas chambers because he chose not to. Levi presents Mertens' position adding his personal reflections:

Non si rendeva conto che la sua obbedienza era un aiuto concreto al regime di Hitler? Sí, oggi sí, ma non allora, non gli era mai venuto in mente. (Didn't he realize that his obedience was a concrete help to Hitler's regime? Yes, today he realized it but back then, he never thought of it.) (Levi, L'ultimo Natale di Guerra, 35)

Levi then concludes using his own judgment and mentioning a letter that he had sent him in previous years in which he had explained his own reasons. He chose again to write, instead of a personal encounter, to express his unequivocal position towards the 'enemy.' Levi went beyond testimony and stated with conviction and without fear that:

Se Hitler è salito al potere, ha devastato l'Europa e ha condotto la Germania alla rovina, è perché molti buoni cittadini tedeschi si sono comportati come lui, cercando di non vedere e tacendo su quanto vede- 
vano. (If Hitler became powerful, devastated Europe and ruined Germany, it is because many good German citizens behaved like him, trying not to see and keeping silent about what they saw.) (Levi, L'ultimo Natale di Guerra, 35)

This is probably one of the very few times in which Levi involved himself in an argument with the 'enemy'. His tone had become more accusatory, but still there was no vengeful attitude, rather a disposition towards comprehension.

With the years, his memories did not change or fade, they increased in clarity with the help of reflections and analysis. His writing enabled him to feel satisfied, his words became his food (and sustenance) and for many years he continually used them to satisfy his hunger. He realized that 'telling' was just the beginning of his journey, his words could not be eternal unless written down. The power of his written words inspired numerous people and still today his 'quiet' tone resonates and speaks for those who cannot speak.

I personaggi di queste pagine non sono uomini, la loro umanità è sepolta, o essi stessi l'hanno sepolta, sotto l'offesa subita o inflitta altrui. (The characters of these pages are not people, their humanity is buried, or they themselves have buried it, under the offense they either suffered or inflicted on others.) (Levi, Se questo è un uomo, 109)

The constant awareness of hunger for Levi was ultimately his life support. When an individual is deprived of food he is compelled to seek anything which might satisfy his need for energy. In the case of Levi the energy came from his undeniable need to write his memories which was his own hunger for life. His appetite for life was inspired and sustained by his writing about his own hunger. In doing so, Levi was able to acquire the necessary understanding of it and find the strength to survive after Auschwitz.

\section{PRINCETON UNIVERSITY}

\section{WORKS CITED}

Arata, Rodolfo. Guerra e Fame. Roma: Cinque Lune, 1968.

Beccaria Rolfi, Lidia. "La memoria dopo il ritorno" in Memoria e Invenzione, 5463.

Beer, Marina. "Memoria cronaca e storia" in Storia generale della Letteratura italiana, XIV (Il Novecento, le forme del Realismo. 2). Eds. Nino Borsellino and Walter Pedullà. Milan: Motta, 2004. 596-621 
Belpoliti, Mario. "Animali e fantasmi." Primo Levi. Lultimo Natale di Guerra. 129-141

Primo Levi. Milan: Mondadori, 1998.

(ed). Primo Levi: Conversazioni e interviste 1963-1987. Turin: Einaudi, 1997.

Brambilla, Rosa; Cacciatore, Giuseppe (eds.). Primo Levi: La dignità dell'uomo. Assisi: Cittadella Editrice, 1995.

Gordon, Robert S.C. (ed.). The Cambridge Companion to Primo Levi, NY: Cambridge University Press, 2007.

Harrowitz , Nancy "Primo Levi's Jewish Writer" in The Cambridge Companion to Primo Levi, 17-31.

Levi, Primo. Se questo è un uomo. Turin: Einaudi, 1989

—. Il sistema periodico. Turin: Einaudi, 1975 and 1994.

—. L'ultimo Natale di Guerra. Ed. Marco Belpoliti. Turin: Einaudi, 2000.

Mattioda, Enrico (ed.). Al di quà del bene e del male, la visione del mondo di Primo Levi. Milan: Franco Angeli, 2000.

Patruno, Nicholas. Understanding Primo Levi. Columbia, S.C.: University of South Carolina Press, 1995.

Poli, Gabriella. "La memoria come impegno e lotta." In Primo Levi: la dignità dell'uomo. 23-30.

Primo Levi: memoria e invenzione. Ed. Giovanna Ioli. Atti del convegno internazionale, San Salvatore Monferrato, 26-28 settembre 1991. San Salvatore Monferrato: Edizioni della Biennale "Piemonte e letteratura," 1995.

Proust, Marcel. À la recherche du temps perdu, Paris: Grasset, 1913- 1927.

Pugliese, Stanislao G. (ed.). The Legacy of Primo Levi. New York: Palgrave Macmillan, 2004

Scarpa, Domenico “'Tutta si confessa.' Primo Levi e il grigiore del passato" in $A l$ di qua del bene e del male. 47-58.

Tallis, Raymond. Hunger. Stockfield TN: Acumen, 2008.

Thomson, Ian, "The Genesis of If This is a Man," The Legacy of Primo Levi. 41-59. 